Saudi Journal of Medicine

Abbreviated Key Title: Saudi J Med ISSN 2518-3389 (Print) |ISSN 2518-3397 (Online) Scholars Middle East Publishers, Dubai, United Arab Emirates Journal homepage: https://saudijournals.com/sjm

Review Article

\title{
Theater in Latin America: Promoting Cerebral Internet in Jungle
}

\section{David Salinas Flores}

Guest Professor, Faculty of Human Medicine, San Marcos National University

DOI: $10.36348 /$ sjm.2020.v05i01.009

| Received: 14.01.2020 | Accepted: 22.01.2020 | Published: 27.01.2020

*Corresponding author: David Salinas Flores

\section{Abstract}

The play "This place does not exist" has been recently released in Peru, it is promoted as a social protest against illegal mining and prostitution of teenagers in the peruvian jungle, however, a scientific analysis reveals that it has actually been carefully designed with a goal : the promotion of brain internet in the jungle. The play belongs to the millionaire media campaign to promote the cerebral internet and digital fascism. The transmission of thoughts from the cerebral Internet via wi-fi is recreated in its advertising that shows an adolescent with an open brain and an recreation of transmission of thoughts, the transmission of private life with cerebral Internet is promoted subliminally under the argument of visibility as the main way of getting out of poverty. Although this play is promoted as a social protest against slavery of teenagers of the jungle actually it promotes sexual slavery with surveillance and mind control of these teenagers with brain net.

Keywords: Internet, Brain-computer Interface, Peru, nanotechnology, privacy.

Copyright @ 2020: This is an open-access article distributed under the terms of the Creative Commons Attribution license which permits unrestricted use, distribution, and reproduction in any medium for non-commercial use (NonCommercial, or CC-BY-NC) provided the original author and source are credited.

\section{INTRODUCTION}

Recently, the play "This place does not exist" has been released in Peru, in Lima art museum's theater auditorium. The play tells the story of a teenager from an Amazonian community who has resorted to prostitution as a means of survival, her community has been victim of illegal mining. The history takes place in a canteen that serves as a hotel, these place are known in the jungle of Peru as "prosti-.bar", they are close to the illegal miners' camps, the characters complain about their economic status, and they yearn for a better future, a "promised land" [1]. This theatrical piece is promoted as a social protest against slavery and exploitation of women in illegal mining áreas [2].

\section{CONTENTS}

Illegal mining generates child exploitation, prostitution, low school enrollment, labor exploitation, citizen insecurity, among other problems. Around 4,500 adult women and girls are sexually exploited in the "prosti -bars", $78 \%$ of them are minor children.
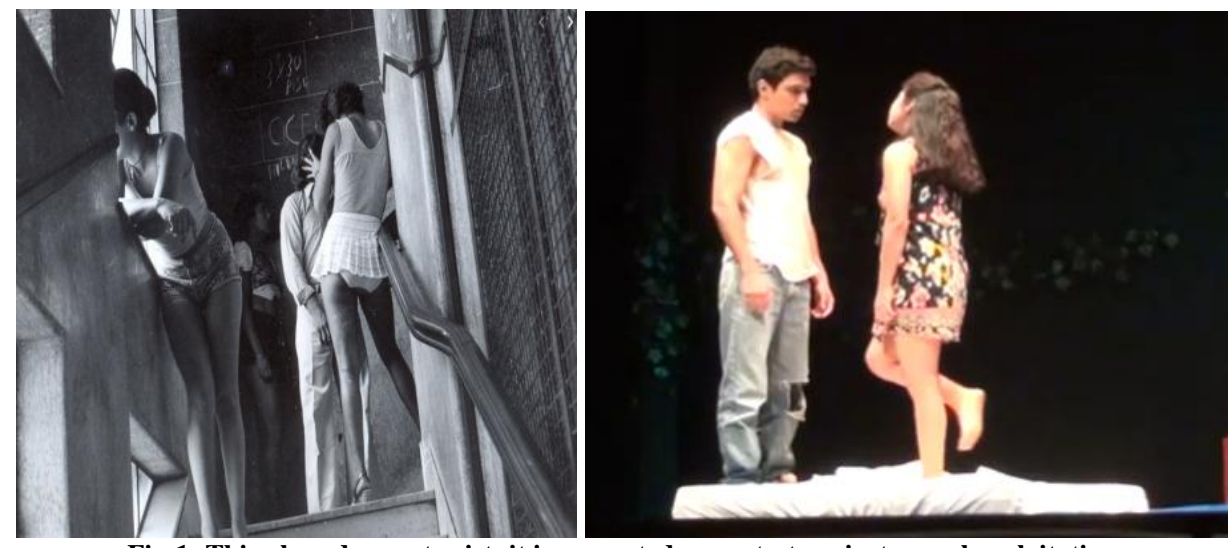

Fig-1: This place does not exist: it is promoted as protest against sexual exploitation Prostibuls in Peruvian jungle are known as prostibars (Left) are recreated in teathrical piece (Right)

Source: Left (Polemos. Page web) Right (picture of this place does not exist) 
This play that recreates this reality is promoted that has been produced to denounce this reality of illegal mining, however a scientific analysis of the play reveals a different message.

Alejandra Vieira, the director of this piece of teather expresses in relation to her work:

"In the end the theater is for an audience, which means that everything is built for someone who should decode it, according to their own cultural background" [3].

The analysis of this play reveals:

The secret code of "This place does not exist" is the cerebral internet

The play is promoted as a theatrical piece of the kind of social protest however the play belongs to the millionaire media campaign to promote the cerebral internet and digital fascism.

Cerebral Internet is a technology of communication developed in a person who has in his brain invasive neurotechnology such as implants, nanobots or microchips.

The two main uses of cerebral internet also known as brain net are:

\section{Teletransmision of life}

The daily life is sent via wi-fi to cell phones, computers and televisions and even to other brains; thus, a tele visualization of the victim's daily life would be done with cerebral internet. In short, any person would see another person's entire life, minute by minute, through a cell phone or computer. For this propiety cerebral internet is also known as "human Tv", "human GPS" and "The eye of God" [4].

\section{Teletransmision of Thoughts}

This is the most amazing propriety of cerebral internet, thus brain net can obtain any kind of thoughts, such as memories and dreams. This use is subliminally promoted in the cover of books that promote cerebral internet with an image that simulates an information transmission from the brain to a cell phone and the phrase: "Thoughts that are read, seen, heard [4].

Scientific researches about cerebral internet only has been reported in experiments with animals, such as monkeys and rats. However scientists like Michio Kaku claim that prototypes already exist and that he has seen them in the laboratory but the most serious fact is that recent investigations warn of forced and secret human experimentation with brain nanobots and microchips in the world, mainly in Latin American universities [4].
The most recent researches about cerebral internet published by Berkeley University [5] could be being developed with information of illicital experimentation with cerebral internet in children peruvian of schools such as Innova Schools.This schools are organized by Berkeley University in Peru, has a advertising that promote innovation, a publicity associated to nanomafias and recent scientific articles alert that Innova School is the main target of mafias of mind control [6]. It is necessary to emphasize that cerebral internet is promoted by futurists as a benefit for the society; however, it is considered the most powerful weapon of violation of intimity and extortion of organized crime, common crime and state terrorism.

The great amount of information obtained with cerebral internet gives immense power of extortion to transnationals of technology such as Google who organize the cerebral internet. Recent expressions of Google's CEO only can be explained with secret experimentation with cerebral internet and reveals the power of extortion of cerebral internet with watching of daily life and reading of thoughts. Eric Schmidt, Executive Chairman Google (2001-2015) said this threatening phrases:

-We know where you are. We know where you've been.

We can more or less know what you're thinking about.

-If you have something that you don't want anyone to know,

maybe you shouldn't be doing it in the first place $[7,8]$.

The real message of all these expressions of Google is: "You should not do anything that opposes the mafia of government and transnationals because we are looking all your life with the cerebral internet,

if you oppose our government mafia, all your private life will be exposed"

However, the most dangerous fact is:

The cerebral internet is the main tool of digital fascism [4, 9]. .

The plutocracy that governs the world has a objective: manufacture the voluntary consent of citizens to accept the use of brain nanobots and the cerebral internet as part of their daily lives. This is the digital fascism, an oligarchy that rules the rest of world citizens who will carry nanobots and will be digital slaves, a human robotisation of the society at the service of a millionaire elite. The digital citizen will be a digital slave, nanobots will make him lose his mind control, thus he would be controlled by others and thus he will lose their autonomy; he can lost his privacy due to being permanently spied on with the cerebral internet. In summary, citizens with brain nanobot 
become human pets of the plutocracy that governs the world.

Society has voluntarily given part of their private lives in emails, facebooks, and telephone calls to the transnationals, former Google CEO sayed:

-With your permission you give us more information about you, about your friends.

Nowadays, with the advance of invasive neurotechnology such as brain microchips and cerebral internet, it is possible that the transnationals of technology such as Google or Facebook can get all the information of a citizen's life such as routine life, memories, dreams, sexual life, among others. As well as the transnationals have achieved to convince citizens to give part of their private life, nowadays, the transnationals want to convince citizens to give all the information of their lives that can be obtained with the cerebral internet. It is necessary to remember that knowledge is power, this large amount of private information gives immense power to transnationals of technology that secretly co-govern the world together with the elected governments.

However, the society reveals little interest in the use of brain nanobots as a recent US survey reveals [9].

In recent scientific articles, the following is expressed:

"Nowadays, human beings using the Intel brain chip voluntarily seem unlikely.

it could probably have applications for people like the quadriplegics [9]."

For that reason, recent research provides evidence that transnational technology companies is resorting to criminal methods. Transnational have chosen a method to achieve this megaobjective:
Friendly fascism considered the new face of power of American stablishment [10].

Classical fascism has been associated with violence, for example Hitler's fascism or Mussolini's fascism.

In Classic fascism the main method is the violence; in friendly fascism the method is swindle, the misleading advertising

Analysts express in books:

- Most of us imagine totalitarianism as something imposed upon us-

But what if we are complicit in our own oppression?

In short, the main objective of friendly fascism is:

Citizens live happy being digital slave, illicitly enriching an elite of millionaires that govern the world. Analysts express that we are heading towards the digital fascism without putting up much of a fight.

So, specialists in marketing are who develop the ideas of American establishment in publicity and different intellectual camouflages with the purpose of deceive society to accept cerebral internet.

"This place does not exist is a tool of friendly fascism

Several features of the play reveal that it has a secret objective: manufacture voluntary acceptance of the cerebral internet. The two main properties of the cerebral internet, the transmission of thoughts and the transmission of daily life are promoted in the work:

Transmission of Thoughts

The main poster of the play show a teenager with an open brain and a flight of thoughts, an advertising that recreates the transmission of thoughts with brain net, the seagulls that leave the brain of the adolescent simulate the waves wi fi (Fig-2).
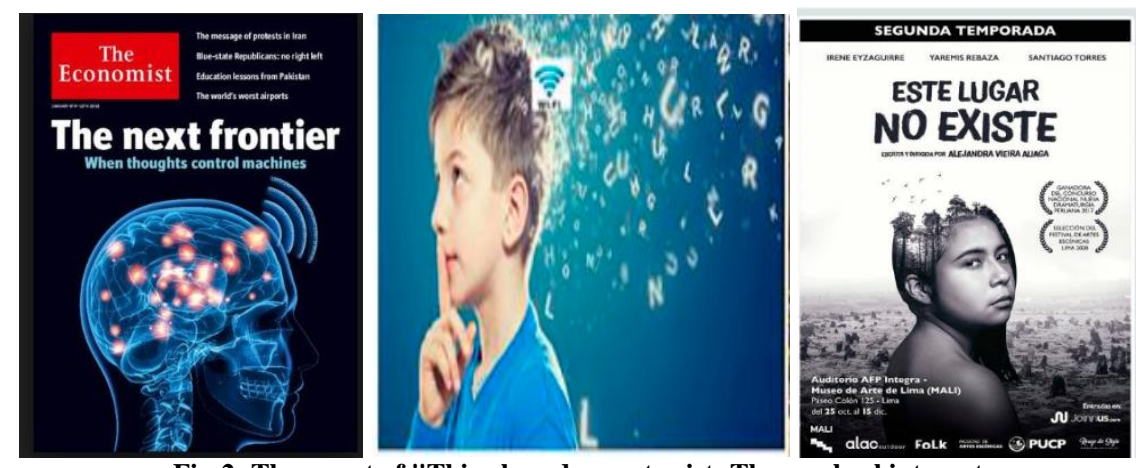

Fig-2: The secret of "This place does not exist: The cerebral internet

The promotion of the cerebral internet (Left and center) the publicity of the theatrical piece is similar to publicity of brain net (Right)

Source: Left (The Economist) Center (ref 11) Right (poster of this place does not exist
This publicity repeats a pattern:

The advertising of "this place does not exist" is the publicity of the "Open Society" 
Actually, Open society is the society with open brain with cerebral internet, where thoughts and entire life are public. Recent researches have analyzed this advertising in Latin American universities such as Yachay and Pontifical Catholic university of Peru as promotion of brain net [11].

Transmission of daily life

The amazonian teenager describes as one of the main factors of her tragedy: Invisibility of her town.

The slogan of the play is:

"Something exists when it is seen and nobody sees us"

The secret message is

With the cerebral internet, everyone will see us, we will exist and the government see our problems, and the authorities will be interested in them, and our reality will improve.

In short:

Visibility with the brain internet is the way out of underdevelopment Visibility is the pretext that the play uses to promote the brain net.

The transmission of daily life is promoted under the pretext of visibility the publicity of the play says;

"In fictions, there are happy endings, but in this harsh reality where many children live, will it be possible to escape? Or does this place not exist?"

Actually, the paradise that promotes the work, as its publicity reveals, is the society with brain net, where your private life and thoughts are public.

The subliminal message of the work express that visibility of the cerebral internet will allow your social inclusion and that your problems could be seen and heard, however, the reality is different, the main objective of transnationals with cerebral internet is to obtain sex life of women for commercialization.

Visibility is one more of the pretexts invented by intellectual scammers for voluntary acceptance of the cerebral internet, in movies such as The Circle [12], there is a subliminal promotion of the use of the cerebral Internet as a symbol of honesty, the message "if you are honest you must accept the cerebral internet", in TV series such as "Person of interest", there is a subliminal promotion of permanent surveillance with the cerebral internet under the pretext of security, the message: "the watchers of the cerebral internet are your angels" [13].

Visibility as an argument to get out of poverty is reinforced by the press that generally acts as a sounding board of cinema and theater, the newspapers emphasizes the message desired by the productor of ther play thus Correo, a Peruvian newspaper express:

"This place does not exist makes visible the problem of illegal mining and some of its terrible consequences in areas such as Madre de Dios: child exploitation, trafficking of persons, prostitution, low schooling, ...

A happy ending is not possible if we do not strive to know this crude reality to become promoters of change" [14].

The subliminal message of the newspaper is:

The required change is visibility and social inclusion with the cerebral internet

Alejandra Vieira, the director of the play expresses a similar subliminal message:

"The happy ending is not possible, until we change this reality"

Based in the publicity and message of the play, the change in reality is the open society with the cerebral internet, the society where an elite of millionaires will have access to the whole life of the rest of society, a society where privacy will be only a luxury for millionaires.

The "Promised Land" spoken by the protagonists will be the citizens of the jungle of Peru with the cerebral internet.

\section{DISCUSION}

Recent researches have investigated the role of films and tv series as promoters of cerebral internet [12, 13] however, there is not analysis of the theatrical pieces in this promotion of brain net.

The choice of a play that has as its main character a prostitute of Peruvian jungle to be used as a promotion of the cerebral internet is not random. Peru is one of the main objectives of nanotechnology mafias called nanomafias [15], and one of the main places of transnationals is the Peruvian jungle for its extensive natural resources.

Recent scientific research warns of a secret epidemic of nanobots in Latin America, mafias of technology transnationals are spreading nanobots in food and beverages [16], for which thousands of women is under espionage and mind control with the cerebral internet, thus sexual life of thousands of teenagers is being watched by this mafia of transnationals of technology and media. The unusual visits of media magnates to jungle communities of Peru such as Cesar Alierta, when was manager of Telefonica in Peru, and the existence of Medical Research Unit Six (NAMRU-6) in the Peruvian jungle, the only US military command located in South America, are facts 
that reinforce the suspect of a mafia of brain internet in the Peruvian jungle. It is necessary to highlight that NAMRUD-6, justify its presence in Peru affirming that its objective is infectious diseases research. However, recent researches alert hat main work of NAMRUD-6 is actually to organize mafias of cerebral internet in Peru [4].

This reality of the Peruvian jungle explains the existence of a brain internet promotion aimed at the jungle population. It is evident that the play seeks to promote the use of cerebral internet in jungle, the two main uses of the cerebral internet are mind control and surveillance of daily life - mainly sex life-. Thus, the play seeks:

\section{Manufacturing voluntary consent of jungle teenagers of spying on their sex life}

The theater is one of the few places where an individual voluntarily accepts the observation of their behavior, "the art of watching and being watched" [17], the presentation of the sexual life of a teenager as a play subliminally seeks to promote the voluntary acceptance of teenagers of the public exposition of their sexual life, which show in a theater.
The secret espionage of the sexual life of the jungle made by transnationals has the need for the production and development of a media campaign with the objective that women of the jungle legally accept the public dissemination of their sexual life and its commercialization as T.V. series -without legal claim

The play seeks to convince the teenager of the jungle coexist with the daily espionage by an elite of millionaires who have access to the private life of everyone woman of the jungle.

In the poster of the publicity of this theater piece, the slogan of the work "this place does not exist" is associated with a paradisiacal image of the jungle and the image of a teenager with an open brain with the cerebral internet thus, the poster reveals the subliminal message that this paradise (the open society with cerebral internet) does not exist yet, however, unfortunately, there are many evidences that alert that thousands of teenagers in the jungle are being spied on with the cerebral internet, thus "the paradise of the jungle with open brain " already exists (Fig-3).
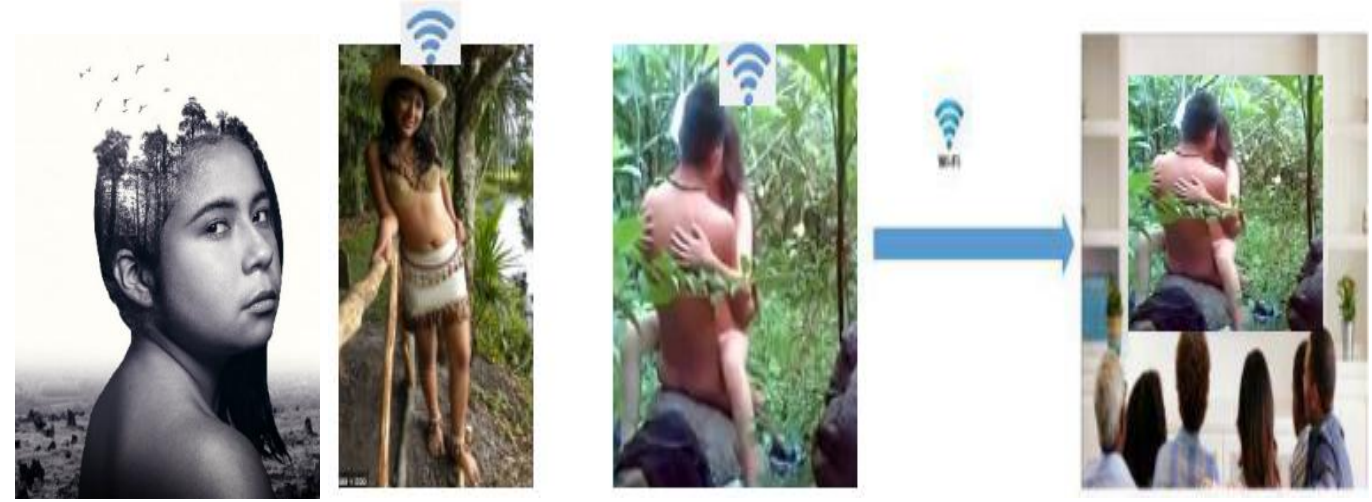

Fig-3: The objective of cerebral internet: The sex life of teenagers of the jungle

The play seeks to promote the use of the brain internet in the jungle (Left and center), the objective of the mafias of cerebral internet mafias is obtain sex life of women. (Right)

Source: Left (poster of this place does not exist) Center and right (Copyright author)

\section{Promotion of mind control and sexual slavery of jungle adolescents}

Mind control is a reductive process in which a man is reduced to an animal, machine or slave. It is a technique aimed at suppressing the will of a person, to make it dependent on what is dictated by another person or organization. All limits to human freedom are imposed by mind control.

\section{A recent scientific article emphasizes:}

"For an act to be considered mind control it must alter the individual's behavior without his consent and this alteration to the behavior of the individual must be the goal of the person or group controlling the alteration" [18].

Mind control has been tried through history, the basic ideas of mind control originated in 1921, in Tavistock, a research center of the British Intelligence Service, and then they were developed in Germany, U.S. mind control weapons can be more powerful than the atomic bombs; their existence remains as one of the greatest secrets of the USA. Recent researches alert about the existence of a secret American mental control program that is secretly developing in the world, mainly in Latin america [19, 20], Tibet [21] and EEUU [22], In Peru, the main organizer of the mental control program is the Embassy of the United States in Peru, it has as main operator the US Navy. There are many evidences that point to the US Navy organize the cerebral internet in the Peruvian jungle as the existence of two military bases in the Peruvian jungle (Madre de Dios e Iquitos) (Fig-4). 

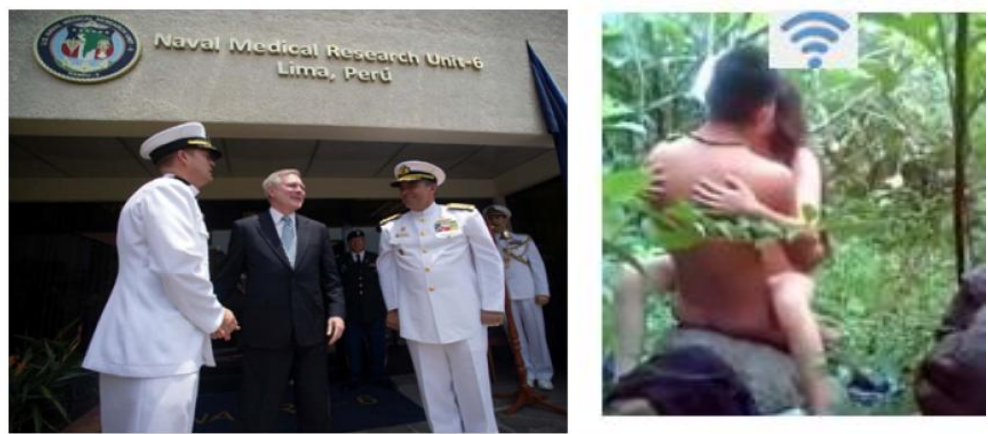

Fig-4: US Navy organize cerebral internet in Peruvian jungle

Naval Medical Research Unit Six (NAMRU-6), the only US military command located in South America (Left). Cerebral internet in the jungle -graphic recreation (Right).

\section{Source: Left Ref 15 Right Copyright author}

This mafia of internet cerebral has as final operators a mafia of journalists that develop mind control with cell phone.

Mental control is developing mainly with this triad of tools: Brain nanobot-cerebral internet-cell phone.

There are many mechanisms of Mind control with brain net [22], among them: extortion with information obtained with brain net, torture with brain net, programation of subconscious mind, induction of actions with brain net that is also known as "the voice of God".

The mafia of mind controllers sends control's signals from her smartphones or computers by wi-fi to victim with brain nanobots, so a mafia of journalists, using the voice of the cerebral internet, could be inducing children and adolescents to commit crimes or to prostitute. "Voice of cerebral internet" becomes a false unconscious, the importance of this fact must be highlighted, because $95 \%$ of our decisions are made by the subconscious mind.
Since there are many evidences that aim to a massive and secret dissemination of brain nanobots in the jungle, thousands of teenagers is being victims of surveillance and mind control. So, Mind control aim to be as a secret megaproblem of public health in the jungle, surprisingly created by own governments and health institutions such as National Health Institute in Peru Naval, Medical Research Unit Six (NAMRU-6), the. Actually, the cerebral internet is creating new problem of health in teenages of jungle.

It is necessary to highlight the role of Pontifical Catholic University of Peru also known as PUCP in this theatrical piece, This university is the main promoter of theater in Peru, Alejandra Vieira, the director of the play, and the actors have strong ties with this university $[3,23]$, recent scientific research warns that Pontifical Catholic University of Peru is the main organizer of cerebral internet in Peru [4, 12]. This university develop brain net in illicital association with a mafia of Peruvian prosecutors and George Soros, who is main promotor of Open society, actually, a camouflage of cerebral internet. Soros has been investing in Facebook, other main organizer of cerebral internet in the world [24, 25].

This university has created centers of innovation such as Open PUCP that aim to be only brain mapping centers with cerebral internet (Fig-5).
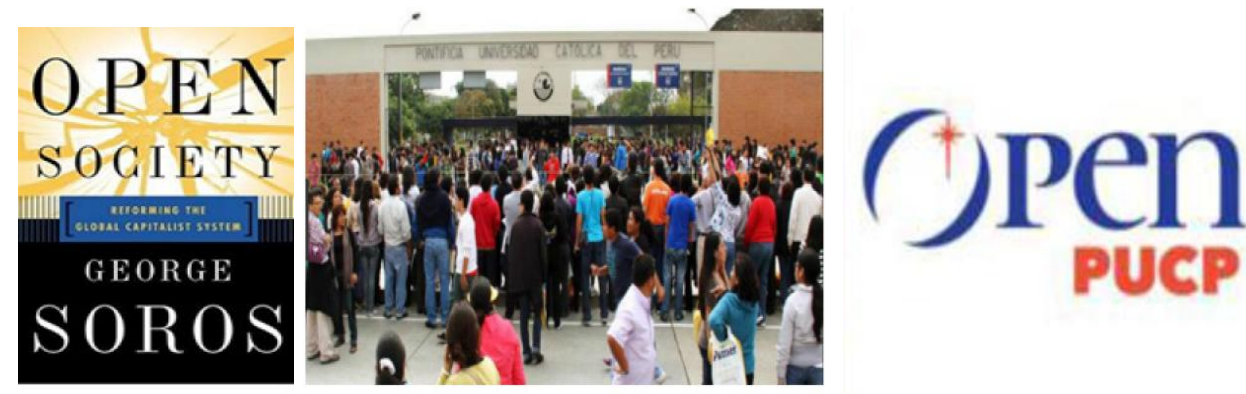

Fig-5: PUC: main promotor of Open Society

George Soros' book about Open Society shows a image that recreate a brain neuron in its frontpage, (Left) Pontifical Catholic University PUC is the main promotor of this society. Recently has open a center "Open PUCP". (Center and right)

Source: Left (Amazon Books) Center (Ref 4) Right (Ref 11) 
Although the producer of the play, ONIRICA, defines herself as an independent theater producer. Actually, the script of "this place does not exist" seemed like a script delivered by the NSA to Alejandra Vieira, - who is the director of the play and creator of the ONIRICA production - a script that could has been developed to help this secret net that make illicit experiments with the cerebral internet in the Peruvian jungle.

In an interview the director says:

Why did you choose that social problem for your work? I did not choose it; it came to me [3].
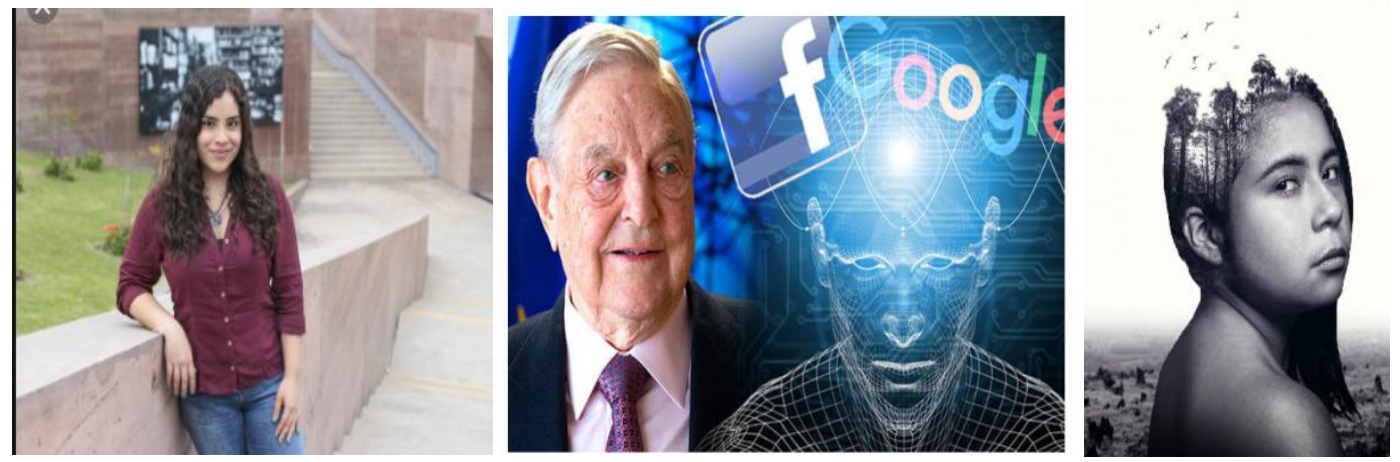

Fig-6: Open Society: The society of Open Brain with brain net

Alejandra Vieira, director of the play, "This place does not exist" with ties with PUC.

(Left) She promotes subliminaly the open society of brain net of George Soros (Center) the publicity of this play is the best evidence (Right)

Source: Left (Ref 23) Center (Ref 24) Right (poster of this place does not exist)

"This place does not exist" has been written and directed by Alejandra Vieira Aliaga, who expresses in interviews about teenagers recreated in the play:

"They are the last link in the chain: without rights, slaves in the 21 st century, the reality is that her play does not seek to protest against slavery, it really seeks to promote slavery, digital slavery with the cerebral Internet.

The choice of this play as a promotion of the cerebral internet is not an isolated event, in Mexico, the theater is also used in the promotion of brain net, with Edward Snowden as its main partner in the promotion, Snowden is promoted by the world press as the agent has reported wortd massive surveillance of NSA however he only has denounced mass surveillance done by computers and supersoftware, he has not reported massive surveillance with cerebral internet, despite that there are many researches that already alert illicital development of cerebral internet in Latin America. It is evident that Snowden knows cerebral internet, but he hides it that is considered, the main weapon of CIA for massive surveillance. Actually, recent research alert that Snowden continue being an agent of the CIA, a main CIA's agent [13].

Snowden participates in the promotion of "Privacy" that is other play also promoted as a social protest [26], however, this play has as publicity that promote cerebral internet, it shows a cell phone with green light placed at the level of the brain giving the subliminal message that the transmission of thoughts with the cerebral internet can be controlled with a cellphone. It is necessary to highlight that Snowden is promoted in association with the Mexican Zapatista movement that emerged in the jungle of Mexico with articles titled: "Snowden was born in the Lacandon jungle" [27]. The subliminal promotion of Snowden as "revolutionary of the jungle" and the promotion of cerebral internet in the play Privacy associated to Snowden points to the existence of a CIA plan to install the cerebral internet in the Mexican jungle, so

"Privacy" and "This place does not exist" share the same objective: Promotion of brain net in the jungle of Latin America.

Theatre is important to build up a culture, throughout time, theater has played an important role in societies all over the world, some societies, such as Ancient Greece, are remembered primarily for their contributions to the theater Theatre remains an important art form for understanding a culture and society, it played a key role in influencing thought. Modern playwrights use theater to express opinions about current events, whether those events are cultural or political. Live theatre helps to promote social discourse, dialogue and potential social change It helps students learn to read and think critically. Thus, the theater that is considered a cultural heritage in many countries, should not be used to promote scams such as the fraud of cerebral internet,

\section{CONCLUSIONS}

The play "This place does not exist" is promoted as a social protest against illegal mining and prostitution of teenagers in the peruvian jungle however, a scientific analysis reveals that it has been 
carefully designed with a goal: the promotion for manufacture the consent of teenagers toward use of cerebral internet, a tool of mind control that can transform teenagers into sex slaves.

\section{REFERENCE}

1. Este lugar no existe. Folk. Nov 2019:25-38

2. El drama de la selva llega al teatro La República 6 de agosto de 2019. Available in: https://larepublica.pe/espectaculos/2019/08/06/eldrama-de-la-selva-llega-al-teatro/

3. Redacción. (2019). Alejandra Vieira, egresada de Artes Escénicas nos invita a las últimas semanas de su obra. PUCP. September 182019 Available In:

http://departamento.pucp.edu.pe/comunicaciones/n oticias/este-lugar-no-existe-alejandra-vieira/

4. Salinas, D. (2018). The Brain net: Violating the privacy of university students. Int Phys Med Rehab J, 3(4), 321-332.

5. Martins, N. R., Angelica, A., Chakravarthy, K., Svidinenko, Y., Boehm, F. J., Opris, I., ... \& Hogg, T. (2019). Human Brain/Cloud Interface. Frontiers in neuroscience, 13, 112.

6. Salinas, D. (2019). Mind control children: Disney's secret script-a critical review of "inside out". Journal of Medical Practice and Review, 3(2):413-431.

7. Orlowski, A. (2010). Google's Schmidt: We know what you're thinking The Register Oct 42010 Available in: https://www.theregister.co.uk/2010/10/04/google_ ericisms/

8. Google CEO On Privacy (VIDEO): If You Have Something You Don't Want Anyone To Know, Maybe You Shouldn't Be Doing $\mathrm{It}^{\text {' }}$ The Huffington Post Dec $6 \quad 2017$ Available in:https://www.huffingtonpost.com/2009/12/07/go ogle-ceo-on-privacy-if_n_383105.htm

9. Salinas, D. (2018). Transhumanism: the big fraudtowards digital slavery. Int Phys Med Rehab $J, 3(5), 381-392$.

10. Gross B. Friendly Fascism: The New Face of Power in America. M. Evans \& Company.1980

11. Salinas, D. (2019). Yachay's secret: The Secret City of US Army's Human Weapon. Journal of Medical Practice and Review, 3(3):461-481

12. Salinas, D. (2019). Cerebral internet: The Circle's secret script. Journal of Medical Practice and Review, 3(1):375-392

13. Salinas, D. (2019). The Secret Of "Person of Interest': The Cerebral Internet. JMCRR, 2(4):171181.

14. Obra "Este lugar no existe" visibiliza el problema de la minería ilegal Correo 28 octubre 2019. Available in: https://diariocorreo.pe/cultura/obra- este-lugar-no-existe-visibiliza-el-problema-de-lamineria-ilegal-919645/

15. Salinas D. (2018). The nanomafia: nanotechnology's global network of organized crime. International Physical Medicine \& Rehabilitation Journal. 3(3):273-277.

16. Salinas D. (2018). El secreto de Hollywood: zombis creados con nanobots cerebrales. Revista de Medicina y Cine, 14(2), 87-91.

17. Woodruf $P$ The Necessity of Theater: The Art of Watching and Being Watched Oxford University Press. 2008.

18. Salinas, D. (2018). Mind Control: From Nazis to DARPA SM Phys Med Rehab J. 2(1):1000-7.

19. Salinas, D. (2018). The secret program of US. mind control weapons: is it developing in latin America? Int Phys Med Rehab Journal, 3(2), 145146.

20. Salinas, D. (2018). Discovering the secret program Of usa mind control. Journal of Medical Practice and Review, 2(10):272-279.

21. Salinas, D. (2019). The Secret of Dalai Lama: Human Robotization of Buddhist Monks. Saudi Journal Med, 4(8):647-659.

22. Salinas D. (2019). Jessica Jones: Mind Control in Tv Series -A Scientific Review. JMPR; 3(6):563580.

23. García, O. (2018). Egresada PUCP gana el Concurso de Nueva Dramaturgia Peruana Puntoedu January 16 2018. Available in: https://puntoedu.pucp.edu.pe/noticias/egresadapucp-gana-el-concurso-de-nueva-dramaturgiaperuana/

24. George Soros invierte en Facebook tras "denunciarlo como amenaza a la sociedad" UFO spain. September 302018 Available in: https://www.ufo-spain.com/2018/09/30/georgesoros-invierte-facebook-tras-denunciarloamenaza-sociedad/

25. Armistead, L. (2012). George Soros 'likes' Facebook with $\$ 10 \mathrm{~m}$ investment The Telegraph August $\quad 15 \quad 2012$ Available in: https://www.telegraph.co.uk/finance/personalfinan ce/investing/9477239/George-Soros-likes-

Facebook-with-10m-investment.html

26. Aristegui C Diego Luna y Edward Snowden discuten sobre "Privacidad" CNN March 72018 Available in: https://cnnespanol.cnn.com/video/diego-lunaedward-snowden-privacidad-dialogo-teatro-intvwaristegui/

27. Gómez, D. M. L. (2015). Snowden nació en la selva Lacandona: reflexiones sobre tecnopolítica y bienes comunes. Revista Teknokultura, 12(3), 577596. 